\title{
Perkembangan Industri Furnitur Kabupaten Jepara Serta Kaitannya dengan Potensi Penerimaan Pajak
}

\author{
Shandy Jannifer Matitaputty; Westri Kekalih \\ Agnes Arie M C; Paulina Rini Hastuti \\ Universitas Katolik Soegijapranata Semarang \\ email:shandy@unika.ac.id
}

\begin{abstract}
Jepara Regency is one of the areas that is the center of the furniture industry in Indonesia. The development of the furniture industry is expected to increase regional income and tax revenue. This study discusses to look at the development of the furniture industry in Jepara Regency, asking for the development of the furniture industry with Jepara Regency revenue as well as potential tax revenues related to the development of the Jepara Regency furniture industry. This research uses quantitative descriptive analysis method. The quantitative descriptive analysis used includes trend analysis, analysis of the furniture industry tax, and Input-Output (I-O) analysis. The results showed; 1 . Furniture Industry in Jepara Regency still has an upward trend of development from year to year both in terms of the number of business units, production volume and number of workers, 2. The Furniture Industry has an important role in developing Jepara Regency in terms of labor, 3 The role / relationship of the furniture / wood material industry in Jepara Regency to other sectors to input suppliers or related future links above the regional average. 4. Increase in taxes in accordance with government taxes, but the potential for tax revenue from the furniture business industry in Jepara Regency shows a positive trend.
\end{abstract}

Keywords: Jepara Regency, Furtinure Industry, Input-Output Analysis, Tax

\begin{abstract}
Abstrak
Kabupaten jepara merupakan salah satu daerah yang menjadi pusat industri furnitur di Indonesia. Perkembangan industri furnitur secara tidak langsung diharapkan akan meningkatkan kemandirian keuangan darah dalam bentuk meningkatnya penerimaan pajak. Penelitian ini bertujuan untuk melihat perkembangan industri furnitur di Kabupaten Jepara, kaitan perkembangan industri furnitur dengan penerimaan Regional Kabupaten Jepara serta potensi penerimaan pajak terkait perkembangan industri furnitur Kabupaten Jepara. Penelitian ini menggunakan metode analisis diskripsi kuantitatif. Analisis diskripsi kuantitatif yang digunakan meliputi analisis trend, analisis kontribusi pajak industri furnitur, serta analisis Input-Output (I-O). Hasil penelitian menunjukkan; 1.Industri Furnitur Kabupaten Jepara masih memiliki trend perkembangan yang meningkat dari tahun ke tahun baik dilihat dari jumlah unit usaha, volume produksi maupun jumlah tenaga kerjanya, 2.Industri Furnitur memiliki peran yang cukup penting terhadap perekonomian Kabupaten Jepara khususnya dalam hal penyerapan tenaga kerja, 3.Peran/ hubungan industri furnitur/ bahan kayu di Kabupaten Jepara terhadap sektor-sektor lainnya lebih kepada penyedia input atau memiliki keterkaitan ke depan yang di atas rata-rata regional, 4.Kenaikan atau penurunan penerimaan pajak sangat terkait dengan kebijakan pemerintah mengenai pajak, akan tetapi potensi penerimaan pajak dari industry usaha furniture pada Kabupaten Jepara menunjukkan tren yang positif.
\end{abstract}

Kata Kunci: Kabupaten Jepara, Industri Furtinur, Analisis Input-Output, Pajak 


\section{PENDAHULUAN}

\section{Latar Belakang}

Salah satu daerah yang menjadi pusat industri furnitur di Indonesia adalah Kabupaten Jepara. Pada Kabupaten Jepara Nilai ekspor Jepara masih didominasi oleh produk furnitur. Komoditas furnitur selalu menduduki posisi teratas. Pada tahun 2016, nilai ekspor furnitur sebesar USD 174.042.524,73 turun menjadi USD 166.862.444,20 pada tahun 2017. Perkembangan nilai ekspor funitur Kabupaten Jepara diharapkan mampu mendongkrak nilai ekspor total Kabupaten Jepara sehingga mampu mengakselerasi pertumbuhan ekonomi daerah dan berkontribusi dalam penyerapan tenaga kerja.

Bertitik tolak dari kondisi tersebut, dapat dikatakan bahwa pergerakan industri furnitur menjadi salah satu pendorong roda perekonomian. Selain menciptakan penyerapan tenaga kerja dan menyediakan barang/ jasa, industri- industri juga merupakan penyumbang penerimaan Negara dan Daerah melalui pembayaran pajak. Hal ini berarti, perkembangan industri furnitur secara tidak langsung akan meningkatkan kemandirian keuangan darah dalam bentuk meningkatnya penerimaan pajak.

\section{Tujuan}

Tujuan umum dari penelitian ini adalah untuk melihat perkembangan industri furnitur dan kaitannya dengan penerimaan serta potensi penerimaan pajak.

\section{METODE}

\section{Data dan Sumber Data}

Data yang akan digunakan dalam penelitian ini adalah data sekunder. Data Sekunder dalam penelitian ini diperoleh dari Badan Pusat Statistik serta publikasi lainnya. Data sekunder dalam penelitian ini menggunakan data runtut waktu serta data antar wilayah.

\section{Metode Analisa}

Penelitian ini menggunakan analisis diskripsi kuantitatif. Analisis diskripsi kuantitatif yang digunakan meliputi analisis trend, analisis kontribusi pajak industri furnitur, serta analisis Input-Output (I-O). Analisis trend digunakan dalam penelitian ini untuk memperkuat perhitungan perkiraan potensi penerimaan pajak yang terkait dengan industri furnitur. Sedangkan metode analisis I-O yang digunakan dalam penelitian ini adaalah analisis tabel dasar, serta analisis keterkaitan/ analisis dampak. Hal ini diperlukan untuk melihat keterkaitan ke depan dan ke belakang industri furnitur dengan sektor lainnya. Dengan mengetahui keterkaitan ke depan dan ke 
belakang, akan diperoleh gambaran pentingnya perkembangan industri furnitur terhadap pergerakan perekonomian dan penerimaan pajak secara keseluruhan.

\section{HASIL}

\section{Kondisi Umum Kabupaten Jepara}

Jepara sebagai salah satu kabupaten di Jawa Tengah dengan luas wilayah 100.413,189 ha, Kabupaten Jepara terdiri dari 16 Kecamatan, 184 Desa dan 11 Kelurahan.

Jumlah Penduduk Kabuaten Jepara pada tahun 2017 sebanyak 1.223.198 orang dengan angkatan kerja sebanyak 640.393 orang yang terdiri dari 609.391 orang bekerja dan 31.002 orang tidak bekerja. Sedangkan tahun 2018 jumlah penduduk meningkat menjadi 1.240.600 orang dengan angkatan kerja sebanyak 641.799 orang yang terdiri dari 617.552 orang bekerja dan 24.247 orang tidak bekerja.

Perkembangan ekonomi Kabupaten Jepara menunjukkan adanya pertumbuhan ekonomi yang cenderung meningkat, yakni 5,10 persen pada tahun 2015; 5,06 persen pada tahun 2016; 5,39 persen pada tahun 2017; dan 5,85 persen pada tahun 2018.

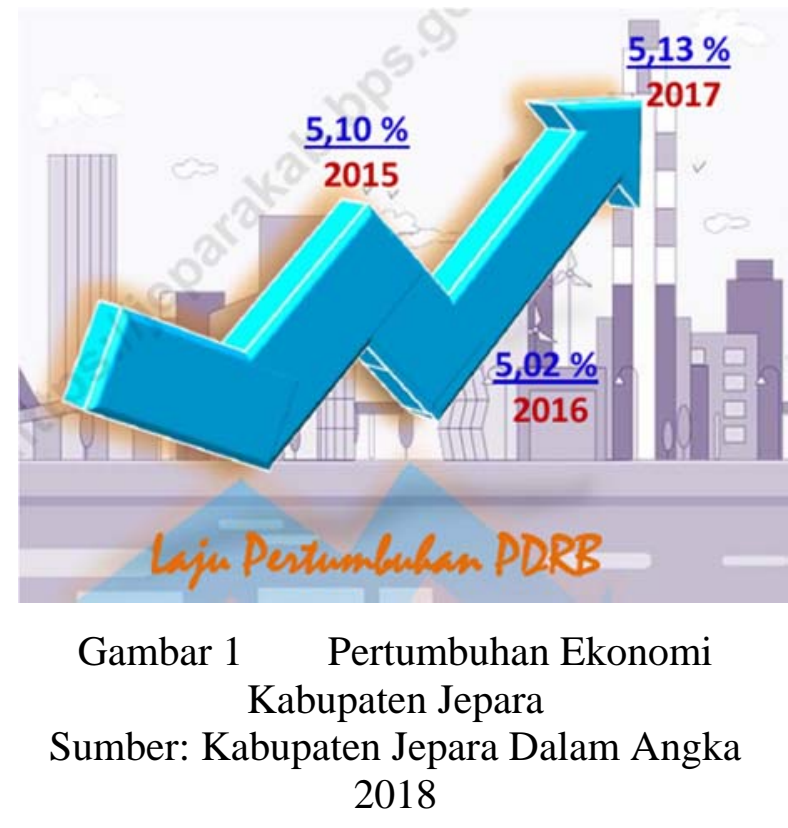

Total Produk Domestik Regional Bruto (PDRB) atas dasar harga konstan 2010 pada tahun 2016, 2017 dan 2018 secara berturut-turut adalah Rp. 18.080,63 miliyar; Rp. 19.054,54 miliyar dan Rp. 20.169,69 miliyar. Nilai total PDB tersebut disumbang oleh tiga sektor terbesar, yakni sektor industri pengolahan, Perdagangan Besar dan Eceran; Reparasi Mobil dan Sepeda Motor serta sektor Sektor pertanian, kehutanan dan perikanan. Ketiga sektor tersebut, masingmasing menyumbang sebesar 34,87 persen, 16,68 persen dan 13,63 persen.

\section{Perkembangan Industri Furnitur Kabupaten Jepara}

Jepara merupakan sentra industri mebel/furnitur Indonesia dan bahkan telah dikenal oleh dunia internasional. Sentra industri furnitur Kabupaten Jepara telah mengalami perkembangan dari waktu ke waktu dan memiliki peran penting terhadap 
perekonomian wilayah. Indusri furnitur Kabupaten Jepara juga dituntut untuk mampu bersaing, berkompetisi di pasar global.

Dapat dilihat pada Gambar 2, secara trend baik jumlah IKM maupun volume produksi meningkat. Sementara itu, pada tahun 2015 ke tahun 2016 jumlah IKM menurun, namun volume produksinya meningkat.

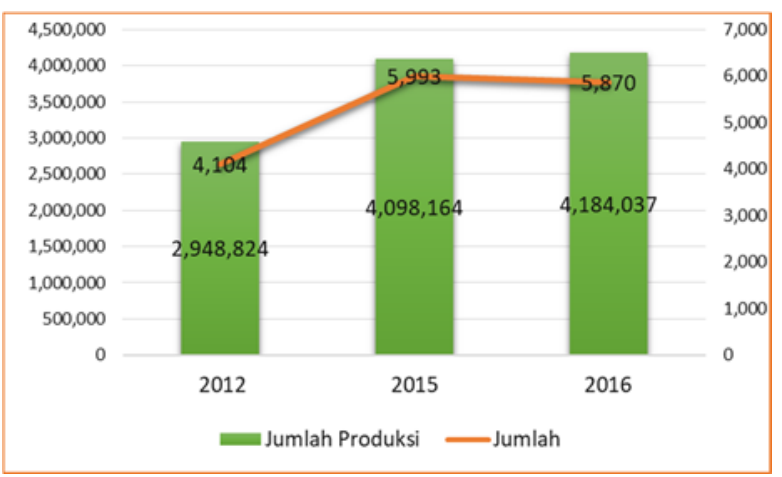

Gambar 2. Perkembangan Jumlah unit usaha dan Volume Produksi Industri Funiture Kayu Kabupaten Jepara. Sumber: BPS, diolah

Industri furnitur kayu merupakan industri dengan jumlah IKM terbanyak. Pada tahun 2012 terdapat 4.104 unit IKM, meningkat menjadi 5.993 unit IKM atau naik sebesar 43,03 persen. Namun demikian, jika membandingkan jumlah IKM pada tahun 2015 dengan 2016, nampak terjadinya penurunan jumlah IKM, yakni menjadi 5.870 unit, atau turun sebesar 2,05 persen. Sementara itu, volume produksi meningkat dari 2.948.824 buah pada tahun 2012 menjadi 4.098.164 buah pada tahun 2015, dan meningkat menjadi 4.184.037 buah pada tahun 2016, atau meningkat sebesar 41,89 persen selama 2012-2015 dan meningkat sebesar 2,10 persen dari tahun 2015-2016.

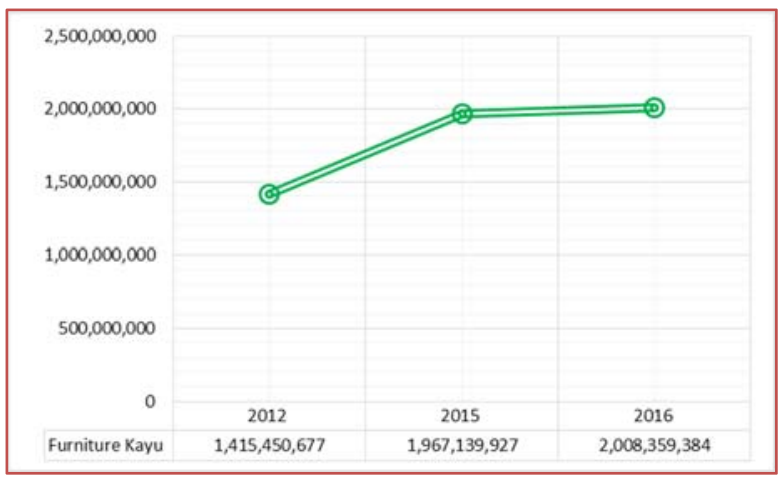

Gambar 3. Perkembangan Nilai Produksi Industri Funitur Kayu Kabupaten Jepara. Sumber: BPS, diolah

Secara keseluruhan dari tahun 2013 2016, jumlah IKM di Kabupaten Jepara mengalami peningkatan. Jumlah IKM pada tahun 2013 hanya sebanyak 13.263 unit usaha, menjadi 14.720 unit usaha pada tahun 2014, 18.612 pada tahun 2015 dan 19.289 unit usaha pada tahun 2016. Dari berbagai jenis IKM yang tumbuh di Kabupaten Jepara, Tabel 1 menunjukkan bahwa jumlah unit usaha furnitur kayu merupakan industri yang sangat dominan, yakni 5.471 unit dari 14.720 unit IKM pada tahun 2014; 5.870 unit dari 18.612 unit IKM pada tahun 2015 dan 5.993 IKM dari 19.289 IKM pada tahun 2016. 
Tabel 1. Perkembangan Jumlah Industri Kecil Menengah (IKM) Kabupaten Jepara

\begin{tabular}{|c|c|c|c|c|c|c|c|c|}
\hline \multirow{3}{*}{$\begin{array}{c}\text { Jenis } \\
\text { Indu } \\
\text { stri } \\
\text { Kecil } \\
\text { Men } \\
\text { enga } \\
\text { h }\end{array}$} & \multicolumn{8}{|c|}{ Industri Kecil Menengah } \\
\hline & \multicolumn{4}{|c|}{ Unit Usaha } & \multicolumn{4}{|c|}{ Tenaga Kerja } \\
\hline & $\begin{array}{l}20 \\
16\end{array}$ & $\begin{array}{l}20 \\
15\end{array}$ & $\begin{array}{l}20 \\
14\end{array}$ & $\begin{array}{l}20 \\
13\end{array}$ & $\begin{array}{c}201 \\
6\end{array}$ & $\begin{array}{c}201 \\
5\end{array}$ & $\begin{array}{c}201 \\
4\end{array}$ & $\begin{array}{c}201 \\
3\end{array}$ \\
\hline $\begin{array}{l}\text { Furni } \\
\text { ture } \\
\text { Kayu }\end{array}$ & $\begin{array}{r}5.9 \\
93\end{array}$ & $\begin{array}{r}5.8 \\
70\end{array}$ & $\begin{array}{r}5.4 \\
71\end{array}$ & $\begin{array}{r}5.3 \\
12\end{array}$ & $\begin{array}{c}77 . \\
187\end{array}$ & $\begin{array}{r}75 . \\
603\end{array}$ & $\begin{array}{r}72 . \\
524\end{array}$ & $\begin{array}{r}70 . \\
412\end{array}$ \\
\hline $\begin{array}{l}\text { Keraj } \\
\text { inan } \\
\text { Rota } \\
\text { n }\end{array}$ & $\begin{array}{r}85 \\
7\end{array}$ & $\begin{array}{r}84 \\
6\end{array}$ & $\begin{array}{r}79 \\
2\end{array}$ & $\begin{array}{r}61 \\
5\end{array}$ & $\begin{array}{r}4.7 \\
26\end{array}$ & $\begin{array}{r}4.6 \\
65\end{array}$ & $\begin{array}{r}4.3 \\
67\end{array}$ & $\begin{array}{r}3.3 \\
91\end{array}$ \\
\hline $\begin{array}{l}\text { Tenu } \\
\text { n Ikat }\end{array}$ & $\begin{array}{r}75 \\
6\end{array}$ & $\begin{array}{r}72 \\
4\end{array}$ & $\begin{array}{r}69 \\
8\end{array}$ & $\begin{array}{r}51 \\
7\end{array}$ & $\begin{array}{r}11 . \\
577\end{array}$ & $\begin{array}{c}11 . \\
087\end{array}$ & $\begin{array}{r}10 . \\
689\end{array}$ & $\begin{array}{r}7.9 \\
18\end{array}$ \\
\hline $\begin{array}{l}\text { Mone } \\
\text { l }\end{array}$ & $\begin{array}{r}59 \\
2\end{array}$ & $\begin{array}{r}63 \\
8\end{array}$ & $\begin{array}{r}61 \\
5\end{array}$ & $\begin{array}{r}58 \\
2\end{array}$ & $\begin{array}{r}1.8 \\
18\end{array}$ & $\begin{array}{r}1.9 \\
59\end{array}$ & $\begin{array}{r}1.2 \\
89\end{array}$ & $\begin{array}{r}1.2 \\
20\end{array}$ \\
\hline $\begin{array}{l}\text { Gera } \\
\text { bah }\end{array}$ & $\begin{array}{r}11 \\
7 \\
\end{array}$ & 94 & 60 & 57 & 452 & 363 & 232 & 221 \\
\hline $\begin{array}{l}\text { Gent } \\
\text { eng }\end{array}$ & $\begin{array}{r}3.9 \\
08\end{array}$ & $\begin{array}{r}3.6 \\
88\end{array}$ & $\begin{array}{r}98 \\
6\end{array}$ & $\begin{array}{r}81 \\
2\end{array}$ & $\begin{array}{c}11 . \\
724\end{array}$ & $\begin{array}{r}11 . \\
064\end{array}$ & $\begin{array}{r}5.3 \\
34\end{array}$ & $\begin{array}{r}4.3 \\
93\end{array}$ \\
\hline $\begin{array}{l}\text { Roko } \\
\mathrm{k} \\
\text { Krete } \\
\mathrm{k}\end{array}$ & 29 & 29 & 68 & 13 & $\begin{array}{r}1.2 \\
54\end{array}$ & $\begin{array}{r}1.2 \\
70\end{array}$ & $\begin{array}{r}1.1 \\
39\end{array}$ & 389 \\
\hline $\begin{array}{l}\text { Keraj } \\
\text { inan } \\
\text { Kayu }\end{array}$ & $\begin{array}{r}1.5 \\
22\end{array}$ & $\begin{array}{r}1.3 \\
46\end{array}$ & $\begin{array}{r}1.0 \\
37\end{array}$ & $\begin{array}{r}87 \\
1\end{array}$ & $\begin{array}{r}9.9 \\
84\end{array}$ & $\begin{array}{r}8.8 \\
30\end{array}$ & $\begin{array}{r}6.8 \\
03\end{array}$ & $\begin{array}{r}5.7 \\
14\end{array}$ \\
\hline $\begin{array}{l}\text { Maka } \\
\text { nan }\end{array}$ & $\begin{array}{r}2.8 \\
65\end{array}$ & $\begin{array}{l}27 \\
88\end{array}$ & $\begin{array}{r}2.6 \\
53\end{array}$ & $\begin{array}{r}2.4 \\
05\end{array}$ & $\begin{array}{r}13 . \\
534\end{array}$ & $\begin{array}{r}13 . \\
171\end{array}$ & $\begin{array}{r}12 . \\
533\end{array}$ & $\begin{array}{r}11 . \\
362\end{array}$ \\
\hline $\begin{array}{l}\text { Konv } \\
\text { eksi }\end{array}$ & $\begin{array}{r}2.0 \\
83\end{array}$ & $\begin{array}{r}2.0 \\
43\end{array}$ & $\begin{array}{r}1.8 \\
24\end{array}$ & $\begin{array}{r}1.5 \\
87\end{array}$ & $\begin{array}{c}11 . \\
781\end{array}$ & $\begin{array}{r}11 . \\
555\end{array}$ & $\begin{array}{c}10 . \\
316\end{array}$ & $\begin{array}{r}8.9 \\
76\end{array}$ \\
\hline $\begin{array}{l}\text { Bordi } \\
\text { r }\end{array}$ & $\begin{array}{r}31 \\
8\end{array}$ & $\begin{array}{r}31 \\
8\end{array}$ & $\begin{array}{r}31 \\
5\end{array}$ & $\begin{array}{r}31 \\
1\end{array}$ & $\begin{array}{r}1.9 \\
24\end{array}$ & $\begin{array}{r}2.0 \\
12\end{array}$ & $\begin{array}{r}1.9 \\
93\end{array}$ & $\begin{array}{r}1.9 \\
68\end{array}$ \\
\hline $\begin{array}{l}\text { Main } \\
\text { an } \\
\text { Anak }\end{array}$ & $\begin{array}{r}24 \\
9\end{array}$ & $\begin{array}{r}22 \\
8\end{array}$ & $\begin{array}{r}20 \\
1\end{array}$ & $\begin{array}{r}18 \\
1\end{array}$ & $\begin{array}{r}1.7 \\
60\end{array}$ & $\begin{array}{r}1.6 \\
12\end{array}$ & $\begin{array}{r}1.4 \\
21\end{array}$ & $\begin{array}{r}1.2 \\
79\end{array}$ \\
\hline & $\begin{array}{r}19 . \\
28 \\
9\end{array}$ & $\begin{array}{r}18 . \\
61 \\
2\end{array}$ & $\begin{array}{r}14 . \\
72 \\
0\end{array}$ & $\begin{array}{r}13 . \\
26 \\
3\end{array}$ & $\begin{array}{r}147 \\
.72 \\
1\end{array}$ & $\begin{array}{r}143 \\
.19 \\
1\end{array}$ & $\begin{array}{r}128 \\
.64 \\
0\end{array}$ & $\begin{array}{r}117 \\
.24 \\
3\end{array}$ \\
\hline
\end{tabular}

Sumber: BPS

Penyerapan tenaga kerja oleh industri furnitur kayu meningkat seiring dengan peningkatan perekonomian dan industri secara keseluruhan. Banyaknya tenaga kerja yang terserap di sektor IKM pada tahun 2014 sebanyak 128.640 orang, pada tahun 2015 sebanyak 143.191 orang dan 147.721 orang pada tahun 2016. Dari seluruh tenaga kerja yang terserap di sektor industri kecil menengah (IKM) tersebut, sebanyak 72.524 orang pada tahun 2014; 75.603 orang pada tahun 2015 dan 77.187 orang pada tahun 2016.
Tabel 2. Perkembangan Nilai Industri Kecil Menengah (IKM) Kabupaten Jepara

\begin{tabular}{|c|c|c|c|c|}
\hline \multirow{2}{*}{$\mathrm{a}$} & Jenis & \multicolumn{3}{|c|}{ Nilai (Rp.000) } \\
\hline & & 2012 & 2015 & 2016 \\
\hline & Furnitur & 1.415 .450 .67 & 1.967.139.92 & 2.008.359.38 \\
\hline 1 & Kayu & 7 & 7 & 4 \\
\hline 2 & $\begin{array}{l}\text { Kerajinan } \\
\text { Rotan }\end{array}$ & 4.792 .043 & 131.540 .760 & 133.251.101 \\
\hline 3 & $\begin{array}{l}\text { Tenun } \\
\text { Ikat }\end{array}$ & 302.884 .726 & 570.932 .805 & 596.167 .404 \\
\hline 4 & Monel & 608.025 & 119.211.764 & 110.616 .558 \\
\hline 5 & Gerabah & 470.804 & 1.469 .981 & 1.829 .657 \\
\hline 6 & Genteng & 5.944 .751 & 221.280 .000 & 234.480 .000 \\
\hline 7 & $\begin{array}{l}\text { Rokok } \\
\text { Kretek }\end{array}$ & 15.444 .027 & 33.880 .577 & 33.453 .735 \\
\hline 8 & $\begin{array}{l}\text { Kerajinan } \\
\text { Kayu }\end{array}$ & 7.944 .345 & 353.502 .157 & 399.725 .322 \\
\hline 9 & Makanan & 15.183 .423 & 32.454 .945 & 33.351 .297 \\
\hline $\begin{array}{l}1 \\
0\end{array}$ & Konveksi & 67.452 .542 & 441.287 .927 & 449.927.925 \\
\hline $\begin{array}{l}1 \\
1\end{array}$ & Bordir & 23.379 .570 & 24.138.641 & 24.167.916 \\
\hline $\begin{array}{l}1 \\
2\end{array}$ & $\begin{array}{l}\text { Mainan } \\
\text { Anak }\end{array}$ & & 19.180.642 & 20.947.280 \\
\hline $\begin{array}{l}1 \\
3 \\
\end{array}$ & $\begin{array}{l}\text { Kerajinan } \\
\text { Simping }\end{array}$ & & 3.900 .342 & 3.436.517 \\
\hline $\begin{array}{l}1 \\
4 \\
\end{array}$ & $\begin{array}{l}\text { Kerajinan } \\
\text { Kuningan }\end{array}$ & & 3.911 .367 & 4.708.127 \\
\hline $\mathrm{a}$ & & $\begin{array}{r}1.859 .554 .93 \\
3 \\
\end{array}$ & $\begin{array}{r}3.923 .831 .83 \\
5 \\
\end{array}$ & $\begin{array}{r}4.054 .422 .22 \\
3\end{array}$ \\
\hline
\end{tabular}

Sumber: BPS.

Seperti halnya perkembangan unit usaha serta penyerapan tenaga kerja, nilai produksi furnitur kayu juga mengalami peningkatkan. Dalam ribuan rupiah, nilai produksi sektor industri sebesar Rp. 1.859.554.933 yang disumbang oleh nilai produksi furnitur kayu sebesar Rp.1.415.450.677 pada tahun 2012, Rp. 3.923.831.835 yang disumbang oleh nilai produksi furnitur kayu sebesar Rp. 1.967.139.927 pada tahun 2015, dan Rp. 4.054.422.223 yang disumbang oleh nilai produksi furnitur kayu sebesar Rp. 2.008.359.384 pada tahun 2016. 


\section{Peran Industri Furnitur Terhadap Perekonomian Kabupaten Jepara}

Dilihat dari perkembangan unit usaha, volume produksi, nilai produksi serta penyerapan tenaga kerja, industri furnitur kayu mengalami tren yang selalu meningkat. Hal tersebut mencerminkan bahwa industri furnitur kayu memiliki peran terhadap perekonomian, baik perannya dalam ketersediaan barang, nilai produksi maupun penyerapan tenaga kerja serta devisa dari ekspor.

Dari seluruh IKM yang ada, 52,13 persen diantaranya adalah industri furnitur kayu. Meskipun bukan mayoritas, industri furnitur kayu juga merupakan industri yang menyerap tenaga kerja terbanyak, yakni 33,27 persen dari seluruh tenaga kerja pada IKM. Peran nilai produksi industri furnitur kayu berperan sebesar 49,54 persen.

Tabel 3. Peran Industri Furniture Kayu terhadap unit usaha, penyerapan Tenaga

Kerja dan Nilai Produksi pada Sektor Industri Kabupaten Jepara Tahun 2016

\begin{tabular}{|c|c|c|c|}
\hline & $\begin{array}{l}\text { \% Unit } \\
\text { Usaha }\end{array}$ & \% Penyerapan TK & $\begin{array}{l}\text { \% Nilai } \\
\text { Produksi }\end{array}$ \\
\hline Furnitur Kayu & 52,13 & 33,27 & 49,54 \\
\hline Kerajinan Rotan & 3,19 & 4,60 & 3,29 \\
\hline Tenun Ikat & 7,82 & 3,72 & 14,70 \\
\hline Monel & 1,23 & 3,55 & 2,73 \\
\hline Gerabah & 0,31 & 0,56 & 0,05 \\
\hline Genteng & 7,92 & 17,48 & 5,78 \\
\hline Rokok Kretek & 0,85 & 0,15 & 0,83 \\
\hline Kerajinan Kayu & 6,74 & 6,74 & 9,86 \\
\hline Makanan & 9,14 & 16,01 & 0,82 \\
\hline Konveksi & 7,96 & 10,60 & 11,10 \\
\hline Bordir & 1,30 & 1,97 & 0,60 \\
\hline Mainan Anak & 1,19 & 0,99 & 0,52 \\
\hline $\begin{array}{l}\text { Kerajinan } \\
\text { Simping }\end{array}$ & 0,11 & 0,11 & 0,08 \\
\hline \multirow[t]{2}{*}{$\begin{array}{l}\text { Kerajinan } \\
\text { Kuningan }\end{array}$} & 0,13 & 0,25 & 0,12 \\
\hline & & 100,00 & 100,00 \\
\hline
\end{tabular}

Sumber: BPS, diolah.
Industri furnitur kayu juga memiliki kontribusi terhadap ekspor, yang berarti mendatangan devisa bagi negara. Baik jumlah eksportir maupun negara tujuan ekspor industri meningkat dari tahun 20122017. Jumlah eksportir pada tahun 2012 hanya sebanyak 312, meningkat sekitar dua kali sampai dengan tahun 2016 menjadi 619 eksportir. Dari sisi negara tujuannya, pada tahun 2012 hanya terdapat 197 negara tujuan, pada tahun 2016 terdapat 327 negara tujuan, namun tahun 2017 mengalami penurunan menjadi 421 negara. Jumlah eksportir industri furnitur dari kayu sebesar 49,60 persen dari seluruh eksportir industri (Gambar 4).

Tabel 4. Jumlah Eksportir dan Negara Tujuan Ekspor Sektor Industri Kabupaten Jepara

\begin{tabular}{|c|c|c|c|c|c|c|c|c|}
\hline \multirow[t]{3}{*}{ Komoditas } & \multicolumn{4}{|c|}{ Jumlah Eksportir } & \multicolumn{4}{|c|}{ Jumlah Negara } \\
\hline & 20 & 20 & 20 & 20 & 20 & 20 & 20 & 20 \\
\hline & 12 & 15 & 16 & 17 & 12 & 15 & 16 & 17 \\
\hline Furnitur & 19 & 29 & 30 & 39 & 10 & 11 & 11 & 11 \\
\hline dari Kayu & 0 & 6 & 7 & 8 & 3 & 3 & 3 & 1 \\
\hline $\begin{array}{l}\text { Kapok/Pro } \\
\text { duk Nabati }\end{array}$ & 2 & 8 & 12 & 5 & 5 & 8 & 20 & 10 \\
\hline $\begin{array}{l}\text { Barang/Ke } \\
\text { masan dari } \\
\text { Plastik }\end{array}$ & 1 & 6 & 4 & 5 & 11 & 8 & 5 & 6 \\
\hline $\begin{array}{l}\text { Kerajinan } \\
\text { Batu, } \\
\text { Semen, } \\
\text { Marmer }\end{array}$ & 7 & 13 & 20 & 11 & 6 & 8 & 11 & 6 \\
\hline $\begin{array}{l}\text { Keramik / } \\
\text { Terakota }\end{array}$ & & 11 & 20 & 6 & & 6 & 15 & 6 \\
\hline $\begin{array}{l}\text { Barang } \\
\text { dari Logam }\end{array}$ & & 11 & 9 & 5 & & 5 & 5 & 6 \\
\hline $\begin{array}{l}\text { Kerajinan } \\
\text { Kayu dan } \\
\text { Handicraft }\end{array}$ & 45 & 50 & 65 & 75 & 21 & 14 & 41 & 27 \\
\hline $\begin{array}{l}\text { Kayu } \\
\text { Olahan }\end{array}$ & 23 & 55 & 69 & 83 & 24 & 39 & 37 & 31 \\
\hline $\begin{array}{l}\text { Kaca dan } \\
\text { Produk } \\
\text { dari Kaca }\end{array}$ & 2 & 31 & 42 & 8 & 2 & 10 & 15 & 4 \\
\hline $\begin{array}{l}\text { Produk } \\
\text { Anyaman }\end{array}$ & & 10 & 12 & 10 & & 8 & 12 & 8 \\
\hline Karet & 1 & 1 & 1 & & 7 & 5 & 7 & \\
\hline $\begin{array}{l}\text { Perlengkap } \\
\text { an Furnitur }\end{array}$ & 35 & 27 & 36 & 5 & 13 & 12 & 19 & 5 \\
\hline $\begin{array}{l}\text { Komoditas } \\
\text { Lainnya }\end{array}$ & 6 & 12 & 22 & 35 & 5 & 9 & 27 & 30 \\
\hline Jumlah/Tot & 31 & 53 & 61 & 42 & 19 & 24 & 32 & 11 \\
\hline al & 2 & 1 & 9 & 1 & 7 & 5 & 7 & 3 \\
\hline
\end{tabular}

Sumber: BPS 


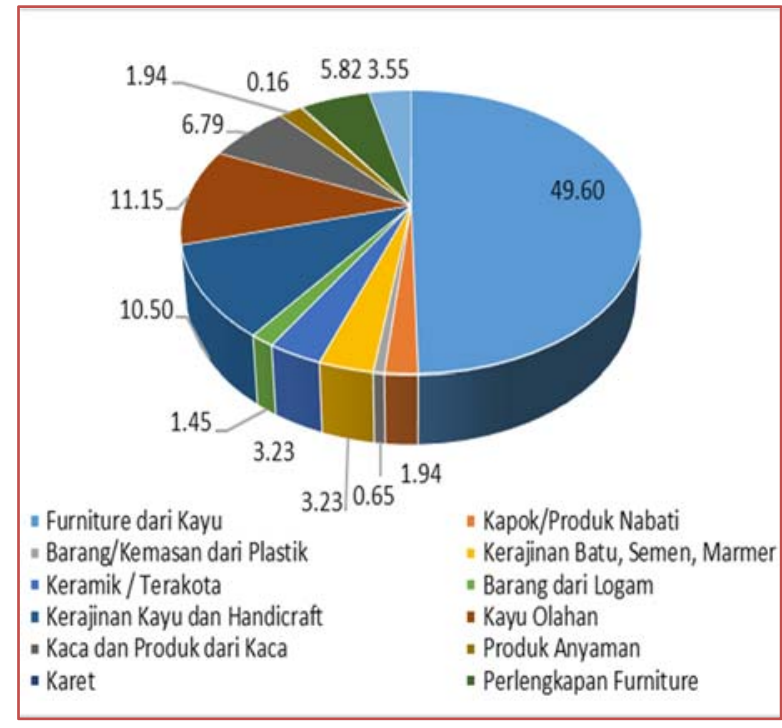

Gambar 4. Distribusi Eksportir Sektor Industri Kabupaten Jepara Tahun 2016 Sumber: BPS, diolah

Volume maupun nilai ekspor industri furnitur dari kayu meningkat sebesar 76,31 persen dari tahun 2012 sampai dengan tahun 2016. Laju pertumbuhan nilai ekpor industri dari kayu meningkat lebih lambat dibandingkan dengan pertumbuhan nilai ekspor industri secara keseluruhan. Pada tahun 2012 sampai dengan tahun 2016 industri secara keseluruhan meningkat dengan laju 74,50 persen, sebesar 23,16 persen pada tahun 2015-2016 dan sebesar 32.22 persen pada tahun 2016-2017. Namun, nilai ekspor furnitur dari kayu hanya tumbuh sebesar 73,47 persen pada tahun 2012-2016, 15,78 persen pada tahun 2015-2016, menurun 4.13 persen pada tahun 2016-2017 (tabel 6).
Tabel 5. Volume Ekspor Sektor Industri Kabupaten Jepara

\begin{tabular}{|c|c|c|c|c|c|}
\hline \multirow[b]{2}{*}{ Komoditas } & \multicolumn{3}{|c|}{ Volume (Kgs) } & \multicolumn{2}{|c|}{ Pertumbuhan } \\
\hline & 2015 & 2016 & 2017 & $\begin{array}{l}2015- \\
2016\end{array}$ & $\begin{array}{l}2016- \\
2017\end{array}$ \\
\hline $\begin{array}{l}\text { Furnitur } \\
\text { dari Kayu }\end{array}$ & $\begin{array}{r}42.2 \\
34.6 \\
09,9 \\
3\end{array}$ & $\begin{array}{r}51.472 \\
.715,5 \\
6\end{array}$ & $\begin{array}{r}45,920 \\
346.50\end{array}$ & 21,87 & $\begin{array}{r}- \\
12.09 \\
\%\end{array}$ \\
\hline $\begin{array}{l}\text { Kapok/Pro } \\
\text { duk Nabati }\end{array}$ & $\begin{array}{r}329 . \\
881, \\
51 \\
\end{array}$ & $\begin{array}{r}1.222 . \\
641,23\end{array}$ & $\begin{array}{r}304,90 \\
9.30\end{array}$ & 270,63 & $\begin{array}{r}- \\
300.99 \\
\% \\
\end{array}$ \\
\hline $\begin{array}{l}\text { Barang/Ke } \\
\text { masan dari } \\
\text { Plastik }\end{array}$ & $\begin{array}{r}863 . \\
908, \\
80 \\
\end{array}$ & $\begin{array}{r}547.04 \\
6,00\end{array}$ & $\begin{array}{r}393,22 \\
8.97\end{array}$ & $-36,68$ & $\begin{array}{r}- \\
39.12 \\
\% \\
\end{array}$ \\
\hline $\begin{array}{l}\text { Kerajinan } \\
\text { Batu, } \\
\text { Semen, } \\
\text { Marmer }\end{array}$ & $\begin{array}{r}68.6 \\
03,6 \\
0\end{array}$ & $\begin{array}{r}200.18 \\
2,14\end{array}$ & $\begin{array}{r}31,654 . \\
16\end{array}$ & 191,80 & $\begin{array}{r}- \\
532.40 \\
\%\end{array}$ \\
\hline $\begin{array}{l}\text { Keramik / } \\
\text { Terakota }\end{array}$ & $\begin{array}{r}33.8 \\
14,7 \\
0 \\
\end{array}$ & $\begin{array}{r}328.50 \\
1,49\end{array}$ & $\begin{array}{r}8,736.2 \\
8\end{array}$ & 871,48 & $\begin{array}{r}- \\
3660.2 \\
0 \% \\
\end{array}$ \\
\hline $\begin{array}{l}\text { Barang dari } \\
\text { Logam }\end{array}$ & $\begin{array}{l}2.69 \\
1,40\end{array}$ & $\begin{array}{r}27.699 \\
, 51\end{array}$ & $\begin{array}{r}9,600.2 \\
0\end{array}$ & 929,19 & $\begin{array}{r}- \\
188.53 \\
\% \\
\end{array}$ \\
\hline $\begin{array}{l}\text { Kerajinan } \\
\text { Kayu dan } \\
\text { Handicraft } \\
\end{array}$ & $\begin{array}{r}346 . \\
936, \\
66 \\
\end{array}$ & $\begin{array}{r}11.750 \\
.035,9 \\
0 \\
\end{array}$ & $\begin{array}{r}1,497,9 \\
51.66\end{array}$ & $\begin{array}{r}3.286,8 \\
0\end{array}$ & $\begin{array}{r}- \\
684.41 \\
\% \\
\end{array}$ \\
\hline $\begin{array}{l}\text { Kayu } \\
\text { Olahan }\end{array}$ & $\begin{array}{l}6.57 \\
5.70 \\
5,30 \\
\end{array}$ & $\begin{array}{r}5.705 . \\
027,56\end{array}$ & $\begin{array}{r}4,339,5 \\
34.39\end{array}$ & $-13,24$ & $\begin{array}{r}- \\
31.47 \\
\% \\
\end{array}$ \\
\hline $\begin{array}{l}\text { Kaca dan } \\
\text { Produk dari } \\
\text { Kaca } \\
\end{array}$ & $\begin{array}{r}25.2 \\
63,6 \\
6 \\
\end{array}$ & $\begin{array}{r}41.459 \\
, 16\end{array}$ & $\begin{array}{r}2,434.1 \\
2\end{array}$ & 64,11 & $\begin{array}{r}- \\
1603.2 \\
5 \% \\
\end{array}$ \\
\hline $\begin{array}{l}\text { Produk } \\
\text { Anyaman }\end{array}$ & $\begin{array}{r}583 . \\
424, \\
43\end{array}$ & $\begin{array}{r}281.07 \\
9,56\end{array}$ & $\begin{array}{r}350,01 \\
8.36\end{array}$ & $-51,82$ & $\begin{array}{r}19.70 \\
\%\end{array}$ \\
\hline Karet & $\begin{array}{l}2.91 \\
4.72 \\
2,00 \\
\end{array}$ & $\begin{array}{r}2.079 . \\
702,00\end{array}$ & & $-28,65$ & \\
\hline $\begin{array}{l}\text { Perlengkap } \\
\text { an } \\
\text { Furniture } \\
\end{array}$ & $\begin{array}{r}71.5 \\
18,4 \\
6 \\
\end{array}$ & $\begin{array}{r}160.05 \\
6,87\end{array}$ & $\begin{array}{r}11,977 . \\
94\end{array}$ & 123,80 & $\begin{array}{r}- \\
1236.2 \\
6 \% \\
\end{array}$ \\
\hline $\begin{array}{l}\text { Komoditas } \\
\text { Lainnya }\end{array}$ & $\begin{array}{r}475 . \\
389, \\
27 \\
\end{array}$ & $\begin{array}{r}9.268 . \\
323,16\end{array}$ & $\begin{array}{r}30,114, \\
353.17\end{array}$ & $\begin{array}{r}1.849,6 \\
3\end{array}$ & $\begin{array}{r}69.22 \\
\%\end{array}$ \\
\hline $\begin{array}{l}\text { Jumlah/Tot } \\
\text { al }\end{array}$ & $\begin{array}{r}54.5 \\
26.4 \\
69,7 \\
2 \\
\end{array}$ & $\begin{array}{r}83.084 \\
.470,1 \\
4\end{array}$ & $\begin{array}{r}118,44 \\
4,670.9 \\
6\end{array}$ & 52,37 & $\begin{array}{r}29.85 \\
\%\end{array}$ \\
\hline
\end{tabular}

Sumber: BPS, diolah 
Tabel 6. Nilai Ekspor Sektor Industri Kabupaten Jepara

\begin{tabular}{|c|c|c|c|c|c|}
\hline \multirow[b]{2}{*}{ Komoditas } & \multicolumn{3}{|c|}{ Nilai Ekspor (US\$) } & \multicolumn{2}{|c|}{ Pertumbuhan } \\
\hline & 2015 & 2016 & 2017 & $\begin{array}{l}2015- \\
2016\end{array}$ & $\begin{array}{c}201 \\
6- \\
201 \\
7\end{array}$ \\
\hline $\begin{array}{l}\text { Furnitur } \\
\text { dari Kayu }\end{array}$ & $\begin{array}{r}150.3 \\
20.77 \\
9,41\end{array}$ & $\begin{array}{r}174.0 \\
42.52 \\
4,73\end{array}$ & $\begin{array}{r}166,8 \\
62,44 \\
4.20 \\
\end{array}$ & 15,78 & $\begin{array}{r}- \\
4.13 \\
\%\end{array}$ \\
\hline $\begin{array}{l}\text { Kapok/Prod } \\
\text { uk Nabati }\end{array}$ & $\begin{array}{r}1.378 . \\
410,4 \\
2 \\
\end{array}$ & $\begin{array}{r}16.38 \\
1.698, \\
73 \\
\end{array}$ & $\begin{array}{l}590,9 \\
44.94\end{array}$ & $\begin{array}{r}1.088, \\
45\end{array}$ & $\begin{array}{r}- \\
96.3 \\
9 \% \\
\end{array}$ \\
\hline $\begin{array}{l}\text { Barang/Ke } \\
\text { masan dari } \\
\text { Plastik }\end{array}$ & $\begin{array}{r}1.748 . \\
360,4 \\
7\end{array}$ & $\begin{array}{r}1.039 . \\
482,4 \\
6 \\
\end{array}$ & $\begin{array}{r}1,560 \\
911.9 \\
5 \\
\end{array}$ & $-40,55$ & $\begin{array}{r}50.1 \\
6 \%\end{array}$ \\
\hline $\begin{array}{l}\text { Kerajinan } \\
\text { Batu, } \\
\text { Semen, } \\
\text { Marmer }\end{array}$ & $\begin{array}{r}44.80 \\
0,89\end{array}$ & $\begin{array}{l}126.4 \\
33,50\end{array}$ & $\begin{array}{r}44,82 \\
2.23\end{array}$ & $\begin{array}{r}182,2 \\
1\end{array}$ & $\begin{array}{r}- \\
64.5 \\
5 \%\end{array}$ \\
\hline $\begin{array}{l}\text { Keramik / } \\
\text { Terakota }\end{array}$ & $\begin{array}{r}32.16 \\
1,92\end{array}$ & $\begin{array}{l}397.8 \\
05,40\end{array}$ & $\begin{array}{r}21,99 \\
9.61\end{array}$ & $\begin{array}{r}1.136, \\
88\end{array}$ & $\begin{array}{r}- \\
94.4 \\
7 \% \\
\end{array}$ \\
\hline $\begin{array}{l}\text { Barang dari } \\
\text { Logam }\end{array}$ & $\begin{array}{r}13.75 \\
2,32\end{array}$ & $\begin{array}{r}82.35 \\
0,55\end{array}$ & $\begin{array}{r}19,05 \\
5.79\end{array}$ & $\begin{array}{r}498,8 \\
1\end{array}$ & $\begin{array}{r}76.8 \\
6 \%\end{array}$ \\
\hline $\begin{array}{l}\text { Kerajinan } \\
\text { Kayu dan } \\
\text { Handicraft }\end{array}$ & $\begin{array}{r}1.719 . \\
057,0 \\
2\end{array}$ & $\begin{array}{r}2.397 . \\
506,1 \\
9\end{array}$ & $\begin{array}{r}3,981, \\
101.1 \\
2\end{array}$ & 39,47 & $\begin{array}{r}66.0 \\
5 \%\end{array}$ \\
\hline $\begin{array}{l}\text { Kayu } \\
\text { Olahan }\end{array}$ & $\begin{array}{r}7.157 . \\
991,3 \\
9\end{array}$ & $\begin{array}{r}6.177 . \\
996,5 \\
9\end{array}$ & $\begin{array}{r}5,587 \\
728.8 \\
9\end{array}$ & $-13,69$ & $\begin{array}{r}- \\
9.55 \\
\%\end{array}$ \\
\hline $\begin{array}{l}\text { Kaca dan } \\
\text { Produk dari } \\
\text { Kaca }\end{array}$ & $\begin{array}{l}113.8 \\
88,52\end{array}$ & $\begin{array}{l}164.6 \\
32,63\end{array}$ & $\begin{array}{r}14,49 \\
5.90\end{array}$ & 44,56 & $\begin{array}{r}- \\
91.2 \\
0 \%\end{array}$ \\
\hline $\begin{array}{l}\text { Produk } \\
\text { Anyaman }\end{array}$ & $\begin{array}{r}1.728 . \\
695,1 \\
9\end{array}$ & $\begin{array}{l}742.8 \\
53,92\end{array}$ & $\begin{array}{r}1,189, \\
247.5 \\
7\end{array}$ & $-57,03$ & $\begin{array}{r}60.0 \\
9 \%\end{array}$ \\
\hline Karet & $\begin{array}{r}4.626 . \\
968,5 \\
7 \\
\end{array}$ & $\begin{array}{r}4.731 . \\
762,9 \\
8 \\
\end{array}$ & & 2,26 & \\
\hline $\begin{array}{l}\text { Perlengkapa } \\
\text { n Furniture }\end{array}$ & $\begin{array}{l}337.1 \\
66,45\end{array}$ & $\begin{array}{r}1.086 . \\
959,8 \\
6\end{array}$ & $\begin{array}{l}109,2 \\
50.99\end{array}$ & $\begin{array}{r}222,3 \\
8\end{array}$ & $\begin{array}{r}- \\
89.9 \\
5 \%\end{array}$ \\
\hline $\begin{array}{l}\text { Komoditas } \\
\text { Lainnya }\end{array}$ & $\begin{array}{r}2.037 . \\
681,2 \\
2 \\
\end{array}$ & $\begin{array}{r}3.558 . \\
014,1 \\
3 \\
\end{array}$ & $\begin{array}{r}11,80 \\
0,304 . \\
68 \\
\end{array}$ & 74,61 & $\begin{array}{l}231 . \\
65 \%\end{array}$ \\
\hline $\begin{array}{l}\text { Jumlah/Tota } \\
\text { l }\end{array}$ & $\begin{array}{r}171.2 \\
59.71 \\
3,79\end{array}$ & $\begin{array}{r}210.9 \\
30.02 \\
1,67 \\
\end{array}$ & $\begin{array}{r}278,8 \\
94,35 \\
4.87 \\
\end{array}$ & 23,16 & $\begin{array}{r}32.2 \\
2 \%\end{array}$ \\
\hline
\end{tabular}

Sumber: BPS, diolah

Nilai ekspor sebesar US\$174.042.524,73, industri furnitur dari kayu menyumbang sebesar 82,51 persen dari total ekspor pada tahun 2016. Artinya, sumbangan dari jenis industri yang lain hanya menyumbang tidak lebih dari 20 persen nilai ekspor Kabupaten Jepara.
Tabel 7. Distribusi Nilai Ekspor Sektor Industri Kabupaten Jepara

\begin{tabular}{|c|l|r|}
\hline a & \multicolumn{1}{|c|}{ Komoditas } & \\
\hline 1 & Furnitur dari Kayu & 82,51 \\
\hline 2 & Kapok/Produk Nabati & 7,77 \\
\hline 3 & Barang/Kemasan dari Plastik & 0,49 \\
\hline 4 & Kerajinan Batu, Semen, Marmer & 0,06 \\
\hline 5 & Keramik / Terakota & 0,19 \\
\hline 6 & Barang dari Logam & 0,04 \\
\hline 7 & Kerajinan Kayu dan Handicraft & 1,14 \\
\hline 8 & Kayu Olahan & 2,93 \\
\hline 9 & Kaca dan Produk dari Kaca & 0,08 \\
\hline 10 & Produk Anyaman & 0,35 \\
\hline 11 & Karet & 2,24 \\
\hline 12 & Perlengkapan Furniture & 0,52 \\
\hline 13 & Komoditas Lainnya & 1,69 \\
\hline Jumlah/Total & 100,00 \\
\hline
\end{tabular}

Sumber: BPS, diolah

\section{Keterkaitan ke belakang dan keterkaitan ke depan industri furnitur terhadap sektor lainnya di Kabupaten Jepara}

\section{Analisis Indeks Total Keterkaitan}

Indeks total keterkaitan merepresentasikan keterkaitan antar sektor dalam suatu sistem perekonomian. Indeks total keterkaitan mencakup indeks total keterkaitan ke belakang dan indeks total keterkaitan ke depan. Indeks total keterkaitan ke belakang menunjukkan keterkaitan satu unit permintaan akhir pada sektor tersebut terhadap total pembelian input semua sektor di dalam suatu perekonomian. Indeks total keterkaitan ke depan menunjukkan keterkaitan satu unit permintaan akhir suatu sektor terhadap total penjualan output semua sektor di dalam suatu perekonomian. 
Keterkaitan ke Belakang/ Analisis backward linkages

Tabel 8 Keterkaitan Kebelakang Langsung Sektor di Kabupaten Jepara

\begin{tabular}{|c|c|c|c|c|c|}
\hline No & $\begin{array}{l}\text { Kode } \\
\text { Sektor }\end{array}$ & $\begin{array}{l}\text { Belakang } \\
\text { Langsung }\end{array}$ & No & $\begin{array}{l}\text { Kode } \\
\text { Sektor }\end{array}$ & $\begin{array}{l}\text { Belakang } \\
\text { Langsung }\end{array}$ \\
\hline 1 & 21 & 0,7436 & 18 & 26 & 0,1654 \\
\hline 2 & 27 & 0,7144 & 19 & 6 & 0,1530 \\
\hline 3 & 20 & 0,6988 & 20 & 9 & 0,1495 \\
\hline 4 & 22 & 0,6898 & 21 & 10 & 0,1384 \\
\hline 5 & 14 & 0,5915 & 22 & 29 & 0,1343 \\
\hline 6 & 17 & 0,5624 & 23 & 12 & 0,1240 \\
\hline 7 & 23 & 0,5603 & 24 & 1 & 0,1227 \\
\hline 8 & 18 & 0,5571 & 25 & 5 & 0,1223 \\
\hline 9 & 19 & 0,5358 & 26 & 31 & 0,1208 \\
\hline 10 & 25 & 0,5048 & 27 & 3 & 0,0943 \\
\hline 11 & 15 & 0,4427 & 28 & 2 & 0,0927 \\
\hline 12 & 28 & 0,3385 & 29 & 7 & 0,0810 \\
\hline 13 & 16 & 0,2868 & 30 & 11 & 0,0809 \\
\hline 14 & 34 & 0,2831 & 31 & 24 & 0,0558 \\
\hline 15 & 30 & 0,2502 & 32 & 8 & 0,0529 \\
\hline 16 & 33 & 0,2108 & 33 & 13 & 0,0290 \\
\hline 17 & 32 & 0,1834 & 34 & 4 & 0,0253 \\
\hline
\end{tabular}

Sumber : Tabel I-O Kabupaten Jepara, diolah

Suatu sektor yang memiliki indeks keterkaitan kebelakang tinggi berarti sektor tersebut memainkan peranan yang cukup penting dalam penyerap input sektor-sektor lainnya. Keterkaitan ke belakang langsung menunjukkan hubungan permintaan akhir suatu sektor terhadap terhadap total pembelian input semua sektor di dalam suatu perekonomian. Sedangkan keterkaitan ke belakang tidak langsung menunjukkan pengaruh tidak langsung antara permintaan akhir suatu sektor terhadap sektor-sektor lainnya yang menyediakan input bagi sektor tersebut. Suatu sektor dikatakan memiliki keterkaitan kebelakang yang besar/ permintaan akhirnya menciptakan pengaruh di atas rata-rata keseluruhan sektor apabila nilainya lebih dari satu.

Tabel 9. Keterkaitan Kebelakang Total Sektor di Kabupaten Jepara

\begin{tabular}{|c|c|c|c|c|c|}
\hline No & $\begin{array}{l}\text { Kode } \\
\text { Sektor } \\
\end{array}$ & $\begin{array}{l}\text { Keterkait } \\
\text { an ke } \\
\text { Belakang } \\
\text { Total } \\
\end{array}$ & No & $\begin{array}{l}\text { Kode } \\
\text { Sektor } \\
\end{array}$ & $\begin{array}{c}\text { Keterkait } \\
\text { an ke } \\
\text { Belakang } \\
\text { Total } \\
\end{array}$ \\
\hline 1 & 21 & 2,4321 & 18 & 26 & 1,2773 \\
\hline 2 & 22 & 2,3687 & 19 & 9 & 1,2534 \\
\hline 3 & 20 & 2,1932 & 20 & 6 & 1,2478 \\
\hline 4 & 27 & 2,1322 & 21 & 10 & 1,2426 \\
\hline 5 & 17 & 2,0351 & 22 & 29 & 1,2281 \\
\hline 6 & 19 & 1,9645 & 23 & 31 & 1,2158 \\
\hline 7 & 14 & 1,8964 & 24 & 1 & 1,2030 \\
\hline 8 & 23 & 1,8546 & 25 & 12 & 1,1961 \\
\hline 9 & 25 & 1,8226 & 26 & 5 & 1,1783 \\
\hline 10 & 18 & 1,8187 & 27 & 2 & 1,1488 \\
\hline 11 & 15 & 1,6007 & 28 & 7 & 1,1406 \\
\hline 12 & 28 & 1,5532 & 29 & 3 & 1,1397 \\
\hline 13 & 34 & 1,5038 & 30 & 11 & 1,1349 \\
\hline 14 & 16 & 1,4162 & 31 & 8 & 1,0830 \\
\hline 15 & 30 & 1,4103 & 32 & 24 & 1,0821 \\
\hline 16 & 33 & 1,3608 & 33 & 13 & 1,0486 \\
\hline 17 & 32 & 1,3288 & 34 & 4 & 1,0427 \\
\hline
\end{tabular}

Sumber : Tabel I-O Kabupaten Jepara, diolah

Secara keseluruhan keterkaitan ke belakang antar sektor di Kabupaten Jepara memiliki angka di atas 1 . Hal ini berarti terdapat keterkaitan yang kuat antar sektor di Kabupaten Jepara dengan sektor yang memiliki kode $(21,22,20,27,17)$ sebagai sektor yang memiliki keterkaitan ke belakang 5 tertinggi. (keterangan sektor dapat di lihat pada lampiran). Sedangkan sektor industi kayu/ bahan kayu (kode sektor 13) lebih memiliki pengaruh/ keterkaitan kebelakang langsung terhadap sektor lainnya. 
Keterkaitan ke Depan/ Analisis forward linkages

Tabel 10. Keterkaitan Kedepan Langsung Sektor di Kabupaten Jepara

\begin{tabular}{cccccc}
\hline No & $\begin{array}{c}\text { Kode } \\
\text { Sektor }\end{array}$ & $\begin{array}{c}\text { Keterkaitan } \\
\text { ke Depan } \\
\text { Langsung }\end{array}$ & No & $\begin{array}{c}\text { Kode } \\
\text { Sektor }\end{array}$ & $\begin{array}{c}\text { Keterkaita } \\
\text { n ke Depan } \\
\text { Langsung }\end{array}$ \\
\hline 1 & 23 & 1,8463 & 18 & 20 & 0,1154 \\
2 & 26 & 1,7545 & 19 & 12 & 0,0956 \\
3 & 14 & 0,7361 & 20 & 10 & 0,0934 \\
4 & 19 & 0,5929 & 21 & 8 & 0,0844 \\
5 & 21 & 0,5926 & 22 & 24 & 0,0833 \\
6 & 28 & 0,5228 & 23 & 1 & 0,0821 \\
7 & 22 & 0,4974 & 24 & 9 & 0,0789 \\
\hline 8 & 13 & 0,3934 & 25 & 34 & 0,0750 \\
\hline 9 & 17 & 0,3857 & 26 & 5 & 0,0644 \\
10 & 6 & 0,3071 & 27 & 4 & 0,0548 \\
11 & 18 & 0,2116 & 28 & 30 & 0,0438 \\
12 & 11 & 0,2073 & 29 & 33 & 0,0404 \\
13 & 25 & 0,1916 & 30 & 3 & 0,0352 \\
14 & 16 & 0,1868 & 31 & 2 & 0,0202 \\
15 & 31 & 0,1725 & 32 & 32 & 0,0183 \\
16 & 15 & 0,1560 & 33 & 7 & 0,0156 \\
17 & 27 & 0,1325 & 34 & 29 & 0,0081 \\
\hline S1 & & 25 & & \\
\hline
\end{tabular}

Sumber : Tabel I-O Kabupaten Jepara, diolah

Keterkaitan ke depan menunjukkan hubungan permintaan akhir suatu sektor terhadap terhadap total penjualan output semua sektor di dalam suatu perekonomian.

Sektor Industri kayu dan bahan kayu (kode sektor 13) termasuk dalam 5 sektor dengan indeks keterkaitan ke depan yang tinggi. Hal ini memberikan gambaran bahwa sektor industri kayu dan bahan dari kayu di Kabupaten jepara masih memiliki pengaruh yang bermakna terhadap penjualan output sektor-sektor lainnya.
Tabel 11. Keterkaitan Kedepan Langsung Sektor di Kabupaten Jepara

\begin{tabular}{|c|c|c|c|c|c|}
\hline No & $\begin{array}{l}\text { Kode } \\
\text { Sektor }\end{array}$ & $\begin{array}{c}\text { Keterkaitan } \\
\text { ke Depan } \\
\text { Total }\end{array}$ & No & $\begin{array}{l}\text { Kode } \\
\text { Sektor }\end{array}$ & $\begin{array}{c}\text { Keterkaita } \\
\text { n ke } \\
\text { Depan } \\
\text { Total } \\
\end{array}$ \\
\hline 1 & 23 & 4,0415 & 18 & 20 & 1,2277 \\
\hline 2 & 26 & 3,8478 & 19 & 8 & 1,2111 \\
\hline 3 & 21 & 2,2147 & 20 & 24 & 1,1466 \\
\hline 4 & 19 & 2,1524 & 21 & 1 & 1,1364 \\
\hline 5 & 13 & 2,0155 & 22 & 34 & 1,1328 \\
\hline 6 & 14 & 1,9924 & 23 & 12 & 1,1280 \\
\hline 7 & 28 & 1,9479 & 24 & 10 & 1,1268 \\
\hline 8 & 22 & 1,8373 & 25 & 9 & 1,1148 \\
\hline 9 & 17 & 1,6105 & 26 & 5 & 1,0753 \\
\hline 10 & 6 & 1,3982 & 27 & 4 & 1,0736 \\
\hline 11 & 31 & 1,3165 & 28 & 30 & 1,0649 \\
\hline 12 & 18 & 1,2939 & 29 & 33 & 1,0553 \\
\hline 13 & 15 & 1,2829 & 30 & 3 & 1,0377 \\
\hline 14 & 11 & 1,2727 & 31 & 7 & 1,0263 \\
\hline 15 & 25 & 1,2499 & 32 & 32 & 1,0262 \\
\hline 16 & 27 & 1,2317 & 33 & 2 & 1,0216 \\
\hline 17 & 16 & 1,2298 & 34 & 29 & 1,0145 \\
\hline
\end{tabular}

Sumber : Tabel I-O Kabupaten Jepara, diolah

Tabel 12. Daya Penyebaran (DP) dan Derajat Kepekaan (DK) Industri/ Sektor di Kabupaten Jepara

\begin{tabular}{|l|c|c|}
\hline Sektor & $\begin{array}{l}\text { Indeks Daya } \\
\text { Penyebaran }\end{array}$ & $\begin{array}{l}\text { Indeks Derajat } \\
\text { Kepekaan }\end{array}$ \\
\hline Primer & 0,814 & 0,961 \\
\hline Sekunder & 1,222 & 1,081 \\
\hline Tersier & 0,964 & 0,958 \\
\hline
\end{tabular}

Sumber : Tabel I-O Kabupaten Jepara, diolah

Daya penyebaran dan derajat kepekaan menunjukkan seberapa besarnya pengaruh pada perhitungan keterkaitan kebelakang dan ke depan. Apabila dikelompokkan ke dalam sektor primer, sekunder dan tersier, sektor sekunder merupakan sektor yang memainkan peran penting di Kabupaten Jepara. Sektor 
sekunder memiliki indeks daya penyebaran dan derajat kepekaan di atas 1. Hal ini menunjukkan sektor sekunder memberikat pengaruh yang kuat terhadap sektor-sektor yang menggunakan hasil outputnya sebagai input ataupun sektor-sektor yang mensupply input untuk sektor tersebut.

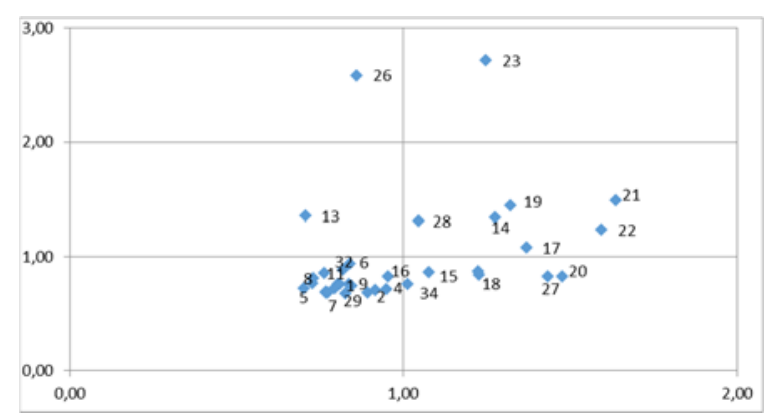

Gambar 5. Daya Penyebaran dan Derajat

Kepekaan Kabupaten Jepara

Sumber: table I-O Kabupaten jepara, diolah

Gambar 5 menampilkan secara lebih mendetail daya penyebaran dan derajat kepekaan sektor di Kabupaten Jepara. Sektor Industri Kayu dan Bahan dari kayu (kode sektor 13) termasuk dalam sektor yang memiliki daya penyebaran kurang dari 1 dan derajat kepekaan lebih dari 1. Hal ini berarti sektor industri kayu lebih berperan sebagai penyedia input bagi sektor lainnya.

\section{Trend dan potensi penerimaan pajak yang} berasal dari Industri furnitur

Sebagai pelaku usaha industri furniture maka tidak dapat dilepaskan dari pajak yang terkait dengan aktivitas kegiatan industri yang terutang pajak, baik itu Pajak Penghasilan (PPh), Pajak Pertambahan Nilai (PPN) maupun Pajak Daerah. Secara nasional realisasi penerimaan pajak dari tahun ketahun selalu mengalami peningkatan, meskipun belum memenuhi dari yang ditargetkan.

Tabel 13 Realisasi Penerimaan Pajak

\begin{tabular}{lccc} 
& & & dalem miliar Rupiah \\
\hline \multicolumn{1}{c}{ Tahun } & $\mathbf{2 0 1 6}$ & $\mathbf{2 0 1 7}$ & $\mathbf{2 0 1 8 ^ { * }}$ \\
\hline Target & $1.355,20$ & $1.283,57$ & $1.424,00$ \\
Realisasi & $1.105,73$ & $1.151,03$ & $1.315,51$ \\
Capaian & $\mathbf{8 1 , 5 9 \%}$ & $\mathbf{8 9 , 6 7 \%}$ & $\mathbf{9 2 , 2 4 \%}$ \\
\hline
\end{tabular}

Sumber: Laporan Kinerja DJP, 2018

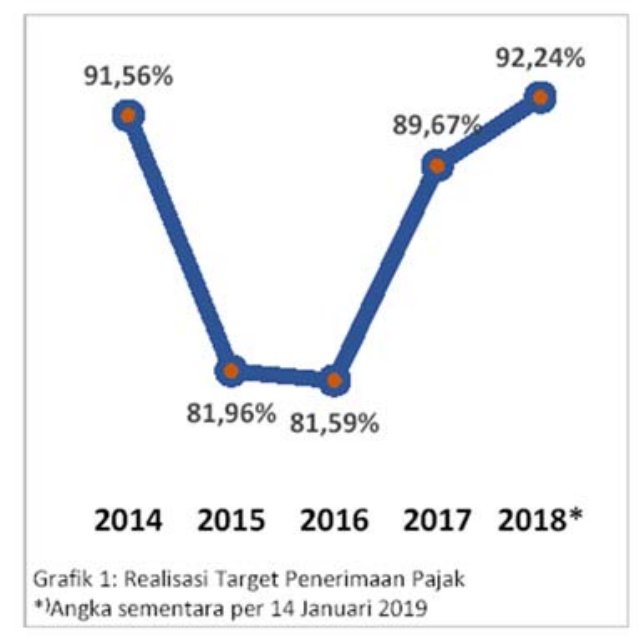

Gambar 6. Persentase Penerimaan Pajak Sumber: Laporan Kinerja DJP, 2018

Dari Tabel 13 dapat dilihat bahwa secara rupiah penerimaan dari tahun ke tahun mengalami peningkatan, begitu pula secara prosentase target penerimaan juga mengalami kenaikan. Sedangkan perkembangan penerimaan dari tahun ke tahun sempat mengalami penurunan kemudian terjadi peningkatan meski besaran peningkatannya (growth) yang terjadi belum stabil, hal ini dapat dilihat dari Gambar 6. 


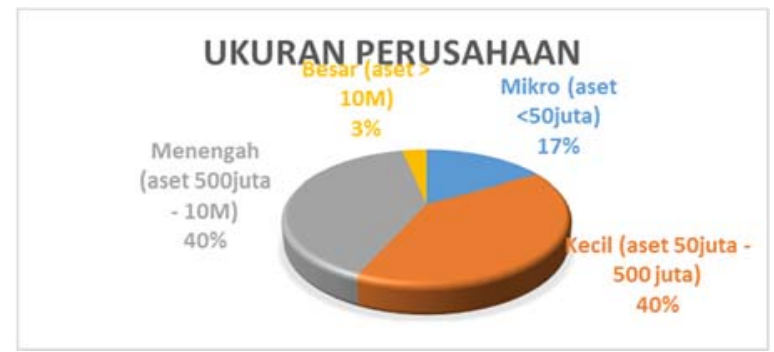

Gambar 7 Ukuran Perusahaan Industri Furnitur di Jepara

Sumber: data diolah, 2018

Sebagian besar pelaku industry furniture di Jepara merupakan pengusaha yang termasuk golongan UMKM yang terdiri dari pengusaha mikro 17\%, pengusaha kecil sebesar 40\%, pengusaha menengah sebesar $40 \%$ serta sisanya sebesar $3 \%$ merupakan pengusaha besar atau yang memeiliki aset lebih dari $10 \mathrm{M}$.

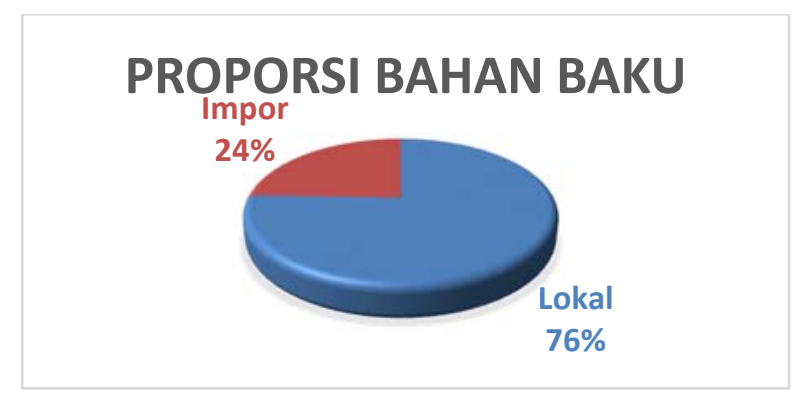

Gambar 8 Proporsi Bahan Baku

Sumber: data diolah, 2018

Dari gambar 8 dapat dilihat bahwa sebagian besar bahan baku diperoleh dari wilayah lokal yakni sebesar 76\%, sedangkan sisanya sebesar 24\% merupakan bahan baku industry yang diperoleh melalui impor dari luar negeri.
Tabel 14 Penerimaan PPh Tahun Pajak 2018

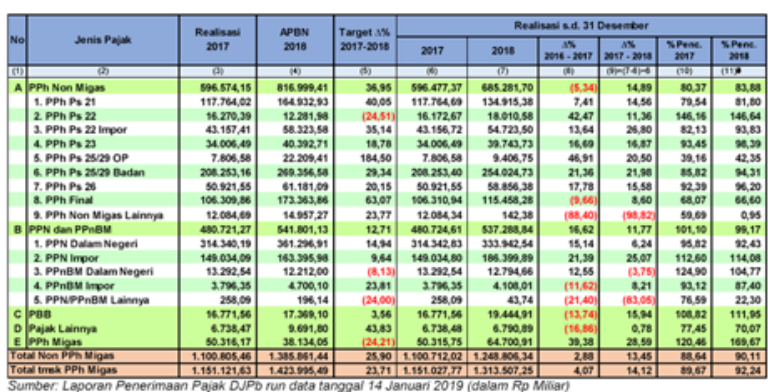

Berdasarkan jenis pajaknya perbandingan penerimaan pajak tahun 2017 dengan tahun 2018 rata-rata mengalami peningkatan kecuali pada penerimaan Pajak yang berkaitan dengan PPnBM Dalam Negeri yang mengalami penurunan sebesar 3,75\%.

Secara penerimaan pajak yang terkait dengan impor memang mengalami penurunan namun jika dilihat secara menyeluruh penurunan ini justru dinilai baik karena adanya penurunan impor, dan bahan baku utama furniture sebagian merupakan impor.

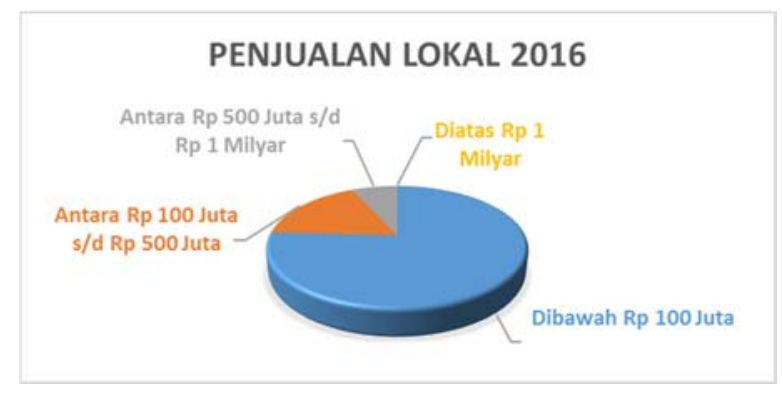

Gambar 9 Penjualan Lokal Industri Furnitur di Jepara Tahun 2016 Sumber: data diolah, 2018 


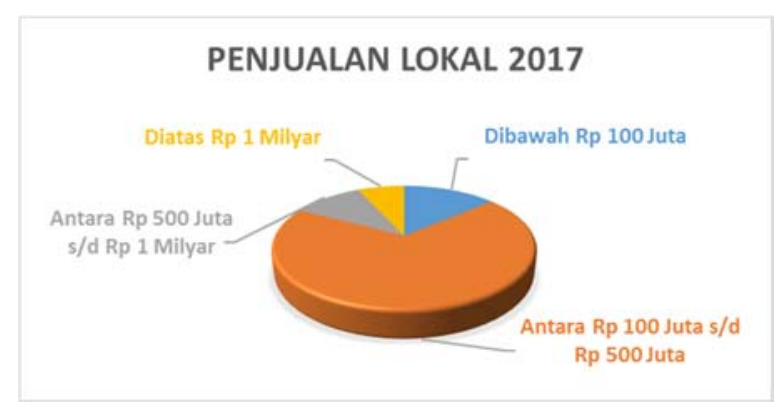

Gambar 10 Penjualan Lokal Industri Furnitur di Jepara Tahun 2017

Sumber: data diolah, 2018

Terjadi peningkatan Penjualan Lokal di tahun 2017 jika dibandingkan dengan tahun 2016. Rata-rata penerimaan penghasilan para pengusaha industry furniture di Jepara masih dibawah Rp 100 Juta Rupiah, akan tetapi justru ditahun 2017 penerimaan penghasilan para pelaku industry furniture di Jepara berada pada angka ratarata diatas Rp100-Rp500 Juta.

Untuk jenis pajak lainnya yang terkait dengan industry furniture adalah Pajak Penghasilan Pasal 21 yang terkait dengan penghasilan karyawan. Industri Furnitur yang ada di Jepara rata-rata merupakan UMKM dimana upah atau gaji yang diberikan kepada karyawan masih relative rendah atau dibawah Penghasilan Tidak Kena Pajak (PTKP).

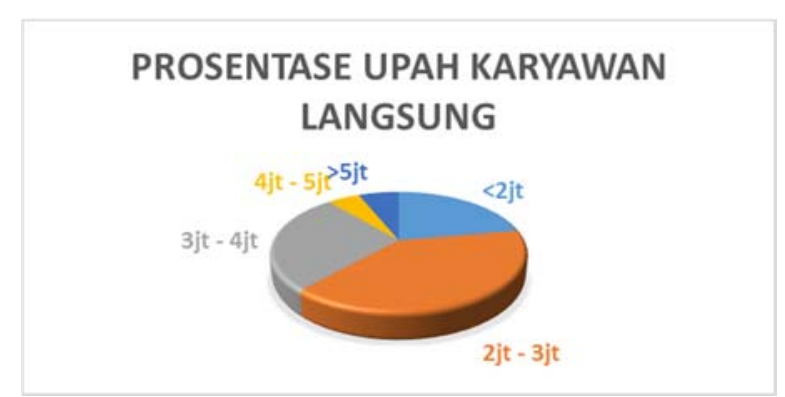

Gambar 11 Upah Karyawan Langsung di Kabupaten Jepara

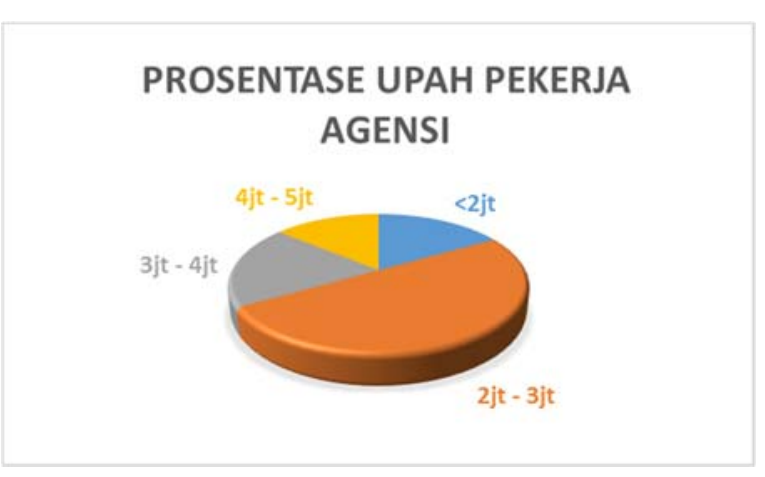

Gambar 12 Upah Pekerja Agensi di Kabupaten Jepara Sumber: data diolah, 2018

Dari Gambar 11 dan Gambar 12 dapat dilihat bahwa baik upah langsung karyawan maupun upah pekerja agensi masih dibawah Rp 5 Juta sehingga peran industry furniture pada Pajak Penghasilan Pasal 21 memang tidak begitu berarti.

Secara jelas karena industry furniture di Jepara rata-rata merupakan UMKM maka terkait dengan pajak UMKM yang dikenakan secara final sebesar $1 \%$ dari penghasilan bruto. Dengan adanya Peraturan Pemerintah Nomor 23 Tahun 2018 dimana tariff PPh atas UMKM turun menjadi 0,5\%. Penurunan tarif tersebut diharapkan mampu membantu UMKM dalam meningkatkan usahanya dan secara makro dapat meningkatkan daya beli masyarakat yang nantinya akan berimbas pada penerimaan pajak dari sektor lainnya. 


\section{KESIMPULAN}

\section{Kesimpulan Penelitian}

1. Industri Furnitur Kabupaten Jepara masih memiliki trend perkembangan yang meningkat dari tahun ke tahun baik dilihat dari jumlah unit usaha, volume produksi maupun jumlah tenaga kerjanya.

2. Industri Furnitur memiliki peran yang cukup penting terhadap perekonomian Kabupaten Jepara khususnya dalam hal penyerapan tenaga kerja

3. Peran industri furnitur di Kabupaten Jepara terhadap sektor-sektor lainnya lebih kepada penyedia input atau memiliki keterkaitan ke depan yang di atas rata-rata regional

4. Kenaikan atau penurunan penerimaan pajak sangat terkait dengan kebijakan pemerintah mengenai pajak, akan tetapi potensi penerimaan pajak dari industry usaha furniture pada Kabupaten Jepara menunjukkan tren yang positif

\section{Saran}

1. Perlunya perhatian khusus terhadap faktor input/ bahan baku industri furnitur melihat angka daya penyebaran yang di bawah 1 .

2. Bagi penelitian selanjutnya, pentingnya peran industri furnitur Kabupaten Jepara terhadap perekonomian Kabupaten Jepara dapat dianalisis lebih jauh menggunakan alat analisis kuantitatif lainnya, seperti analisis angka multiplier atau metode analisis lainnya.

\section{DAFTAR PUSTAKA}

Badan Pusat Statistik (BPS) Kabupaten Jepara. (2019). Produk Domestik Regional Bruto Kabupaten Jepara, Retrieved from bps.go.id

Badan Pusat Statistik (BPS) Kabupaten Jepara. (2019). Daerah Dalam Angka Kabupaten Jepara. Retrieved from bps.go.id

Badan Pusat Statistik (BPS) Kabupaten Jepara. (2001). Tabel I-O Kabupaten Jepara Tahun 2001. Retrieved from bps.go.id

Badan Pusat Statistik (BPS) Kabupaten Jepara. (2008). Tabel I-O Kabupaten Jepara Tahun 2008. Retrieved from bps.go.id

Cooper, D.R, dan C.W., Emory. (2001). Business Research Meyhods, 8th Edition. USA: Richard D. Irwin Inc.

Direktorat Jenderal Pajak. (2017). Laporan Kinerja Kementerian Keuangan Republik Indonesia Direktorat Jenderal Pajak Tahun 2017. Retrieved from www.kemenkeu.go.id

Direktorat Jenderal Pajak. (2018). Laporan Kinerja Kementerian Keuangan Republik Indonesia Direktorat Jenderal Pajak Tahun 2018. Retrieved from www.kemenkeu.go.id

Mardiasmo. (2011). Perpajakan Edisi Revisi 2011. Yogyakarta: Andi Offset.

Marzuki. (2005). Metodologi Riset. Yogyakarta: Ekonisia.

Pujoalwanto, Basuki. (2014).. Perekonomian Indonesia Tinjauan Historis, Teoritis, dan Empiris. Yogyakarta : Graha Ilmu.

Resmi, Siti. (2009). Perpajakan : Teori dan Kasus. Jakarta : Salemba Empat.

Pemerintah Republik Indonesia. (2014). Undang-Undang Nomor 3 Tahun 
2014 Tentang Perindustrian.

Retrieved from kemenperin.go.id

Pemerintah Republik Indonesia. (2007).

Undang-Undang Nomor 28 Tahun

2007

Tentang Ketentuan Umum dan Tata Cara

Perpajakan. Retrieved from

https://www.dpr.go.id

Pemerintah Republik Indonesia. (2008).

Undang-Undang Nomor 36 Tahun 2008 Tentang Pajak Penghasilan.

Retrieved from www.pajak.go.id

Waluyo. (2010). Perpajakan Indonesia.

Jakarta: Salemba Empat 